\title{
Yerba Mate Tea Extract: a Green Approach for the Synthesis of Silica Supported Iron Nanoparticles for Dye Degradation
}

\author{
Natália S. F. Trotte, Mariana T. G. Aben-Athar and Nakédia M. F. Carvalho* \\ Instituto de Química, Edifício Haroldo Lisboa da Cunha, Universidade do Estado do Rio de \\ Janeiro, 20550-013 Rio de Janeiro-RJ, Brazil
}

\begin{abstract}
This work describes a green approach to the synthesis of iron nanoparticles supported in silica using tea extract of the South American plant yerba mate (Ilex paraguariensis). Catalysts with different iron contents were obtained according to the reaction conditions employed. Characterization by X-ray powder diffraction (XRD) and scanning electron microscopy (SEM) revealed the amorphous nature of the nanoparticles, tentatively ascribed to iron(II)/iron(III) oxide composites, as Fourier transform infrared (FTIR) and thermogravimetric analyses confirmed their functionalization by the tea polyphenolic compounds. For the sake of comparison, crystalline zero-valent iron nanoparticles were prepared by the classical method using $\mathrm{NaBH}_{4}$. Both materials were tested in the degradation of methyl orange and led to complete decolourization; the green nanoparticles were very active as heterogeneous Fenton-like catalysts in presence of hydrogen peroxide, while the nanoparticles prepared with $\mathrm{NaBH}_{4}$ were efficient in the reductive degradation of the dye.
\end{abstract}

Keywords: iron nanoparticles, yerba mate tea extract, methyl orange degradation, chemical reduction, heterogeneous Fenton

\section{Introduction}

In the last decades, concerns with environmental problems as water contamination have challenged the scientists to develop sustainable remediation processes. Dye wastes from textile industries need proper treatment before disposal in natural effluents; otherwise, serious health problems to human and aquatic life can be caused. Organic dyes are stable, resistant to bioremediation and highly toxic to human and aquatic life. To minimize their negative effect, chemical methods of remediation have been developed; ${ }^{1-4}$ for instance, the treatment with iron nanoparticles..$^{5-10}$ The main advantages of iron are the low toxicity, biodegradability, low cost, and abundance, besides high chemical reactivity and affinity for the substrate, ${ }^{11-13}$ and magnetic properties. ${ }^{14-18}$ The widespread application of iron nanomaterials in heterogeneous Fenton-like system, an advanced oxidative process, leads to decomposition of organic compounds via generation of highly reactive hydroxyl radicals. ${ }^{19}$

Recently, there is an increasing interest in the preparation of environmentally friendly and sustainable metal and metal

*e-mail: nakedia@uerj.br oxides nanoparticles using natural reducing agents. Plants extracts are good candidates for this purpose, once they contain polyphenolic compounds that can reduce the metal ion and at the same time cap the nanoparticles surface, protecting from aggregation and degradation reactions. ${ }^{20}$ Green iron nanoparticles prepared in presence of green tea (Camellia sinensis) have been successfully applied in the degradation of malachite green ${ }^{21}$ and bromothymol, ${ }^{22}$ and similar catalysts prepared in presence of Australian native plants were able to degrade acid black $194 .{ }^{23}$ However, most of the green nanoparticles reports addresses the preparation of non-supported catalysts, which form residual iron slush and prevents the catalyst recyclability, with the exception of the iron nanoparticles supported on clay successfully applied in the removal of arsenic(III). ${ }^{24}$

More detailed characterization of iron nanoparticles synthesized using green tea revealed the progressive reduction of $\mathrm{Fe}^{3+}$ to $\mathrm{Fe}^{2+}$ during the preparation to form nanoparticles of amorphous nature, while the nanoparticles prepared by the borohydride reduction method were identified as crystalline zero-valent iron nanoparticles. ${ }^{25}$ Comparison between the degradation of methylene blue and methyl orange (MO) dyes showed that green iron nanoparticles are more effective as Fenton-like catalyst 
than zero-valent analogues due to their rich composition of iron oxides/oxohydroxides. ${ }^{26}$

This work reports the green synthesis of iron nanoparticles by tea extracts of the South America polyphenol-rich plant yerba mate (Ilex paraguariensis) $;{ }^{27}$ supported in silica gel, a non-expensive, non-toxic, readily available and acid support. The effect of synthesis conditions in the organic and iron content of the catalysts was investigated. For the sake of comparison, iron nanoparticles prepared by $\mathrm{NaBH}_{4}$ were also obtained with different iron contents. Both materials were applied in the degradation of the dye methyl orange.

\section{Experimental}

\section{Materials}

All chemicals are of reagent grade and were used without further purification. Methyl orange was recrystallized before handling. Hydrogen peroxide $(30 \%$ aqueous solution) was titrated by the iodometric method. Silica gel (0.063-0.200 mm) was purchased from Merck (Darmstadt, Germany). Toasted yerba mate tea was purchased from Mate Leão brand (São Paulo, SP, Brazil) in local market.

Solution ultraviolet-visible (UV-Vis) spectra were recorded in a diode-array Agilent 8453 spectrophotometer (Santa Clara, CA, USA) in water. Scanning electron microscope (SEM) images were obtained using a JEOL JSM-6510LV (Tokyo, Japan) microscope, where the catalysts samples were previously covered with Au (Denton Vacuum model DESKV, Moorestown, NJ, USA). Images of the samples were recorded at an operating voltage of $5 \mathrm{kV}$. The $\mathrm{X}$-ray powder diffraction (XRD) patterns were measured in a Rigaku Ultima IV diffractometer (Tokyo, Japan) with Ni-filtered $\mathrm{CuK}_{\beta}$ radiation source $(\alpha=0.15406 \mathrm{~nm}$, graphite monochromator, $40 \mathrm{kV}$ and $20 \mathrm{~mA}$ ) in the $2 \theta$ angle range between 5 and $80^{\circ}$, at a step width of $0.1^{\circ}$, counting $5 \mathrm{~s}$ between each step. The iron concentration in the catalysts was determined by atomic absorption spectroscopy (AAS; Varian, model 240, Palo Alto, CA, USA) or by X-ray fluorescence analysis using a Rigaku RIX-3100 fluorescence spectrometer (Tokyo, Japan). Fourier transform infrared (FTIR) analyses were carried out in a Nicolet 6700, Thermo Fisher Scientific spectrometer (Waltham, MA, USA), with $\mathrm{KBr}$ pellets. Thermogravimetric and derivative thermogravimetric analysis (TGA/DTG) were carried out in a Netzsch thermogravimetric system (STA 449 Jupiter, Selb, Germany). The system is equipped with a high precision balance to monitor the mass variation as a function of time. Ten miligrams of the sample was heated from 50 to $900{ }^{\circ} \mathrm{C}$, at a rate of $10^{\circ} \mathrm{C} \mathrm{min}^{-1}$, under He flow $\left(45 \mathrm{~mL} \mathrm{~min}^{-1}\right)$. Gas chromatographic analyses were conducted on a HP 6890 gas chromatograph (Palo Alto, CA, USA) with a HP-5MS column $(30 \mathrm{~m} \times 0.25 \mathrm{~mm} \times 0.25 \mu \mathrm{m})$ connected to an electron impact mass detector, using $\mathrm{He}\left(1.4 \mathrm{~mL} \mathrm{~min}^{-1}\right)$ as carrier gas. The analysis conditions for the degradation products were: initial temperature of $50^{\circ} \mathrm{C}$ (hold for $5 \mathrm{~min}$ ), heating ramp of $20{ }^{\circ} \mathrm{C} \mathrm{min}{ }^{-1}$ to $300{ }^{\circ} \mathrm{C}$. The injector and detector temperature was $250{ }^{\circ} \mathrm{C}$. The products were identified by their mass spectra. Electrospray ionization mass spectrometry (ESIMS) analysis were carried out at a triple quadrupole mass spectrometer API 2000 (Applied Biosystems, Foster City, CA, USA), in methanol: $\mathrm{H}_{2} \mathrm{O}(1: 1)$, by direct infusion into the ionization chamber.

\section{Catalysts synthesis}

\section{Synthesis using $\mathrm{NaBH}_{4}$}

Zero-valent iron nanoparticles supported in silica gel were synthesized using the liquid-phase reduction method, as previously reported. ${ }^{9}$

$$
\begin{aligned}
& 4 \mathrm{Fe}^{3+}+3 \mathrm{BH}_{4}^{-}+9 \mathrm{H}_{2} \mathrm{O} \rightarrow 4 \mathrm{Fe}^{0}+3 \mathrm{H}_{2} \mathrm{BO}_{3}{ }^{-}+ \\
& 12 \mathrm{H}^{+}+\mathrm{H}_{2} \uparrow
\end{aligned}
$$

Three ${ }^{x \%} \mathrm{Fe} / \mathrm{SiO}_{2}$ composites with different iron contents (50, 25 and 5 wt.\%) were prepared. For the synthesis of ${ }^{50 \%} \mathrm{Fe} / \mathrm{SiO}_{2}, 19.36 \mathrm{~g}\left(3.46 \times 10^{-1} \mathrm{~mol}\right)$ of $\mathrm{FeCl}_{3} 6 \mathrm{H}_{2} \mathrm{O}$ were dissolved in $400 \mathrm{~mL}$ of water and ethanol at a volume ratio of $4: 1$, and $4.00 \mathrm{~g}$ of silica gel were added to the solution. The mixture was stirred for 15 min under argon atmosphere, and then $0.47 \mathrm{~mol} \mathrm{~L}^{-1} \mathrm{NaBH}_{4}$ aqueous solution $\left(7.11 \mathrm{~g} / 1.88 \times 10^{-1} \mathrm{~mol}\right.$ in $\left.400 \mathrm{~mL}\right)$ was added at the speed of 1-2 drops per second into the mixture under vigorous stirring. The mixture color turned from red brown to light yellow, and then eventually to black. After all the $\mathrm{NaBH}_{4}$ solution had been added, the mixture was stirred for another $20 \mathrm{~min}$. The solid was filtered under reduced pressure and it was quickly rinsed three times with ethanol to prevent the oxidation of the iron $(0)$ particles. The black solid was dried under reduced pressure for $3 \mathrm{~h}$ in a rotary evaporator. Mass obtained: $12 \mathrm{~g}$.

${ }^{25 \%} \mathrm{Fe} / \mathrm{SiO}_{2}$ and ${ }^{5 \%} \mathrm{Fe} / \mathrm{SiO}_{2}$ were prepared by the same procedure, with $6.42 \mathrm{~g}\left(1.15 \times 10^{-1} \mathrm{~mol}\right)$ and $0.97 \mathrm{~g}$ $\left(1.73 \times 10^{-2} \mathrm{~mol}\right)$ of $\mathrm{FeCl}_{3} \cdot 6 \mathrm{H}_{2} \mathrm{O}$, respectively; $2.35 \mathrm{~g}$ $\left(6.21 \times 10^{-2} \mathrm{~mol}\right.$ in $130 \mathrm{~mL}$ of $\left.\mathrm{H}_{2} \mathrm{O}\right)$ or $0.36 \mathrm{~g}\left(9.52 \times 10^{-3} \mathrm{~mol}\right.$ in $20 \mathrm{~mL}$ of $\mathrm{H}_{2} \mathrm{O}$ ) of $\mathrm{NaBH}_{4}$ were used, respectively. Mass

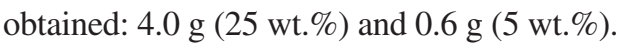

Non-supported zero-valent iron nanoparticles were prepared by the same methodology for control experiments.

The iron concentration was determined by AAS analysis: $0.20 \mathrm{~g}$ of catalyst was digested by treatment with aqua regia, hydrofluoric acid, under heating, until complete 
dissolution of the catalyst. Afterwards, the sample was treated with hydrochloric acid and boric acid and the volume was completed to $100 \mathrm{~mL}$. ${ }^{50 \%} \mathrm{Fe} / \mathrm{SiO}_{2}: 915.4 \mathrm{mg} \mathrm{L}^{-1}$; ${ }^{25 \%} \mathrm{Fe} / \mathrm{SiO}_{2}: 418.2 \mathrm{mg} \mathrm{L}^{-1} ;{ }^{5 \%} \mathrm{Fe} / \mathrm{SiO}_{2}: 103.6 \mathrm{mg} \mathrm{L}^{-1}$; ${ }^{50 \%} \mathrm{Fe} / \mathrm{SiO}_{2}$ after reaction: $922.0 \mathrm{mg} \mathrm{L}^{-1}$.

\section{Synthesis using yerba mate tea extract}

The tea extract was prepared from $25 \mathrm{~g}$ of toasted yerba mate tea in $100 \mathrm{~mL}$ of water at $80^{\circ} \mathrm{C}$ for $1 \mathrm{~h}$. Leaves were filtered off at reduced pressure and let to cool down to room temperature. ${ }^{23,28}$ The total polyphenol concentration (TPCo) of the extract, $0.5373 \mathrm{~g} \mathrm{GA} \mathrm{L}^{-1}$, was determined by the Folin-Ciocalteu method. ${ }^{29}$

Four ${ }^{\mathrm{YM}} \mathrm{Fe} / \mathrm{SiO}_{2}$ composites with theoretical iron content of $14 \mathrm{wt} . \%$ were prepared at different reaction conditions. For the synthesis of ${ }^{\mathrm{YM} 1} \mathrm{Fe} / \mathrm{SiO}_{2}, 2.323 \mathrm{~g}\left(5.75 \times 10^{-3} \mathrm{mols}\right)$ of $\mathrm{Fe}\left(\mathrm{NO}_{3}\right)_{3} \cdot 9 \mathrm{H}_{2} \mathrm{O}$ were dissolved in $50 \mathrm{~mL}$ of water $\left(0.12 \mathrm{~mol} \mathrm{~L}^{-1}\right)$, and $2 \mathrm{~g}$ of silica gel were added to the solution. A hundred milliliter of tea extract was added dropwise into the mixture under vigorous stirring during $20 \mathrm{~min}$. The mixture color turned from red brown to black. The mixture was stirred for another $20 \mathrm{~min}$. The solid was filtered under reduced pressure and the black solid was dried under reduced pressure for $3 \mathrm{~h}$ in a rotary evaporator. Mass obtained: $2.53 \mathrm{~g}$.

${ }^{\mathrm{YM} 2} \mathrm{Fe} / \mathrm{SiO}_{2},{ }^{\mathrm{YM} 3} \mathrm{Fe} / \mathrm{SiO}_{2}$ and ${ }^{\mathrm{YM} 4} \mathrm{Fe} / \mathrm{SiO}_{2}$ were prepared by the same procedure, however, using twice the volume of tea extract $(50.0 \mathrm{~g}$ of leaves in $200 \mathrm{~mL})$. Besides, ${ }^{\mathrm{YM}}{ }^{\mathrm{Fe}} \mathrm{F} / \mathrm{SiO}_{2}$ was prepared under ice bath and ${ }^{\mathrm{YM} 4} \mathrm{Fe} / \mathrm{SiO}_{2}$ at room temperature under argon atmosphere. Mass obtained: $2.82 \mathrm{~g}\left({ }^{\mathrm{YM} 2} \mathrm{Fe} / \mathrm{SiO}_{2}\right) ; 1.70 \mathrm{~g}\left({ }^{\mathrm{YM} 3} \mathrm{Fe} / \mathrm{SiO}_{2}\right) ; 2.00 \mathrm{~g}\left({ }^{\mathrm{YM} 4} \mathrm{Fe} / \mathrm{SiO}_{2}\right)$.

Non-supported iron nanoparticles in presence of tea extract $\left({ }^{\mathrm{YM}} \mathrm{Fe}\right)$ were prepared by the same methodology of ${ }^{\text {YM}} 2 \mathrm{Fe} / \mathrm{SiO}_{2}$ without silica gel.

The iron concentration was determined by $\mathrm{X}$-ray fluorescence analysis, since the digestion procedure did not work well for these samples, a glue was obtained due the decomposition of phenolic compounds, preventing their analysis by AAS. ${ }^{\text {YM1 }} \mathrm{Fe} / \mathrm{SiO}_{2}: 6.122$ wt.\% $\mathrm{Fe}_{2} \mathrm{O}_{3}, 93.878$ wt. $\% \mathrm{SiO}_{2}$; ${ }_{\text {YM } 2} \mathrm{Fe} / \mathrm{SiO}_{2}: 15.185$ wt. $\% \mathrm{Fe}_{2} \mathrm{O}_{3}, 84.815$ wt. $\% \mathrm{SiO}_{2}$; ${ }^{\mathrm{YM}}{ }^{3} \mathrm{Fe} / \mathrm{SiO}_{2}: 1.782$ wt.\% $\mathrm{Fe}_{2} \mathrm{O}_{3}, 98.210$ wt.\% $\mathrm{SiO}_{2}$; ${ }^{\mathrm{YM} 4} \mathrm{Fe} / \mathrm{SiO}_{2}: 23.241$ wt. $\% \mathrm{Fe}_{2} \mathrm{O}_{3}, 76.759$ wt. $\% \mathrm{SiO}_{2}$.

\section{Decolourization tests of methyl orange (MO)}

Stock solution of MO was prepared in distilled water, which reached a $\mathrm{pH}$ value of 5.0. The acidic or basic stock solutions were prepared by addition of diluted $\mathrm{HCl}$ or $\mathrm{NaOH}$ until the desired $\mathrm{pH}$, determined by a digital $\mathrm{pHmeter}$.

Batch experiments were carried out in a glass flask with a flat bottom. The degradation reactions were investigated under different conditions, including mass of catalyst, initial $\mathrm{pH}$, reaction temperature, and concentration of $\mathrm{H}_{2} \mathrm{O}_{2}$. The absorbance of the dye at different time intervals was determined spectrophotometrically.

After the decolourization reaction was completed, the water was removed under reduced pressure and the residue was redissolved in methanol or dichloromethane for analyses by gas chromatography-mass spectrometry (GC-MS) and ESI-MS.

The catalyst efficiency decolourization of MO was calculated using the following equation:

Decolourization $(\%)=\left[\left(\mathrm{Abs}_{0}-\mathrm{Abs}_{\mathrm{t}}\right) / \mathrm{Abs}_{0}\right] \times 100$

where $\mathrm{Abs}_{0}$ is the absorbance of $\mathrm{MO}$ at time $=0$, and $\mathrm{Abs}_{\mathrm{t}}$ was the absorbance of $\mathrm{MO}$ at time $\mathrm{t}(\mathrm{min})$.

Tests with the catalysts synthesized using $\mathrm{NaBH}_{4}$

In a typical experiment, $100 \mathrm{~mL}$ of a $5 \times 10^{-5} \mathrm{~mol} \mathrm{~L}^{-1}$ MO stock solution was added to a desired mass of catalyst, under a water bath at the desired temperature, magnetically stirred. At preset time intervals, samples were taken by a glass syringe and filtered trough $0.45 \mu \mathrm{m}$ membrane filter.

Reactions were carried out in presence of $\mathrm{H}_{2} \mathrm{O}_{2} 30 \%$, added after the reduction step or at the beginning of the reaction. $\mathrm{MO}: \mathrm{H}_{2} \mathrm{O}_{2}$ molar ration of $10^{4}$ and $10^{6}$ were tested, at neutral and acidic $\mathrm{pH}$, at $25^{\circ} \mathrm{C}$.

Catalyst recycling was carried out with $30 \mathrm{~mL}$ of $5.0 \times 10^{-5} \mathrm{~mol} \mathrm{~L}^{-1} \mathrm{MO}$ solution and $39.60 \mathrm{mg}$ of ${ }^{50 \%} \mathrm{Fe} / \mathrm{SiO}_{2}$, in a Falcon tube. After $1 \mathrm{~h}$ of reaction, the catalyst was centrifuged and the solution analyzed by UV-Vis. To the recovered catalyst, a new aliquot of $30 \mathrm{~mL}$ of dye was added and it was allowed to react for another hour. The procedure was repeated until the dye decolourization had decreased considerably.

Tests with the catalysts synthesized using yerba mate tea extract

In a typical experiment, $2 \mathrm{~mL}$ of $5.0 \times 10^{-4} \mathrm{~mol} \mathrm{~L}^{-1}$ MO stock solution, a given volume of $\mathrm{H}_{2} \mathrm{O}_{2}$, and $\mathrm{H}_{2} \mathrm{O}$ to complete $20 \mathrm{~mL}$, were added to a desired mass of catalyst. The reaction was carried out under a water bath at the desired temperature, magnetically stirred. At preset time intervals, samples were taken by a glass syringe and filtered through a $0.45 \mu \mathrm{m}$ membrane filter.

\section{Results and Discussion}

\section{Characterization of the $\mathrm{Fe} / \mathrm{SiO}_{2}$ catalysts}

The XRD patterns of the $\mathrm{Fe} / \mathrm{SiO}_{2}$ catalysts prepared 
using $\mathrm{NaBH}_{4}$ at different iron contents (Figure 1a) showed diffraction peaks that correspond to a body-centered cubic $\alpha-\mathrm{Fe}^{0}$ particles, the peak at $2 \theta=44.76^{\circ}$ corresponds to the (1 110 ) plane, while the peak at $65.16^{\circ}$ corresponds to the (2 00 ) plane. The peak around $2 \theta=20-25^{\circ}$ was assigned to the hexagonal structure of silica gel. ${ }^{30}$ AAS analyses (Table 1) revealed that the supported iron content was close to the starting iron percentage: $45.8 \mathrm{wt} . \%$ for ${ }^{50 \%} \mathrm{Fe} / \mathrm{SiO}_{2}$; 20.9 wt. $\%$ for ${ }^{25 \%} \mathrm{Fe} / \mathrm{SiO}_{2} ; 4.8$ wt. $\%$ for ${ }^{5 \%} \mathrm{Fe} / \mathrm{SiO}_{2}$.

On the other hand, XRD patterns of the $\mathrm{Fe} / \mathrm{SiO}_{2}$ catalysts prepared using yerba mate tea extract (Figure 1b) lack well defined peaks related to crystalline iron compounds. The non-supported ${ }^{\mathrm{YM}} \mathrm{Fe}$ presented large peaks around 25 and $43^{\circ}$, which was also observed in the supported catalysts and could be due to iron materials of very poor crystallinity or to organic matter. ${ }^{23}$ This behavior was also reported by other groups; iron nanoparticles prepared by green tea extract were deficient at the peak of $\mathrm{Fe}^{0}$ and the authors attributed it to their amorphous nature as the iron surface is capped and stabilized by the polyphenols..$^{21,26,31}$ Other authors have also reported a complete amorphous sample, for instance, iron nanoparticles prepared using Australian native plants as Eucalyptus tereticornis, Melaleuca nesophila and Rosemarinus officinalis. ${ }^{23}$ However, for other catalysts, peaks of iron oxides were observed, which did not appear in our case. ${ }^{32,33}$ It is important to point out that the catalyst prepared under argon atmosphere, ${ }^{\mathrm{YM} 4} \mathrm{Fe} / \mathrm{SiO}_{2}$, did not show any peak related to $\mathrm{Fe}^{0}$ as well. According to Markova et al.,${ }^{25}$ the polyphenolic compounds from tea do not possess a reduction potential negative enough to reduce from $\mathrm{Fe}^{3+}$ to $\mathrm{Fe}^{0}$, but can reduce from $\mathrm{Fe}^{3+}$ to $\mathrm{Fe}^{2+}$ forming oxides/hydroxides nanoparticles. X-Ray fluorescence spectroscopy revealed that the supported iron content in ${ }^{\text {YM1 }} \mathrm{Fe} / \mathrm{SiO}_{2}$ was lower (4.3 wt.\%) than the initial iron salt percentage (14.0 wt.\%). Using twice the amount of tea extract in ${ }^{\mathrm{YM} 2} \mathrm{Fe} / \mathrm{SiO}_{2}$, an increase of more than two-folds in the iron content was obtained (10.6 wt.\%). Synthesis using ice-bath did not increase the iron content and only $1.2 \mathrm{wt} . \%$ was obtained for ${ }^{\mathrm{YM} 3} \mathrm{Fe} / \mathrm{SiO}_{2}$. The catalyst ${ }^{\mathrm{YM} 4} \mathrm{Fe} / \mathrm{SiO}_{2}$ prepared under argon atmosphere presented the highest iron content, $16.2 \mathrm{wt} \%$, favoring the reduction of the iron(III) precursor to iron nanoparticles, as demonstrated by recent works. ${ }^{25,34}$

Figure 2 shows SEM micrographs of the $\mathrm{Fe} / \mathrm{SiO}_{2}$ catalysts synthesized by $\mathrm{NaBH}_{4}$, the morphology is similar to the free iron(0) nanoparticles (Figure S2). The images revealed that the iron particles formed crystalline aggregates, constituted of filaments of united spheres, in accordance with the literature. ${ }^{35,36}$ The particles are well dispersed over the silica surface, but they do not cover the support completely (Figures S3-S5). Conversely, the
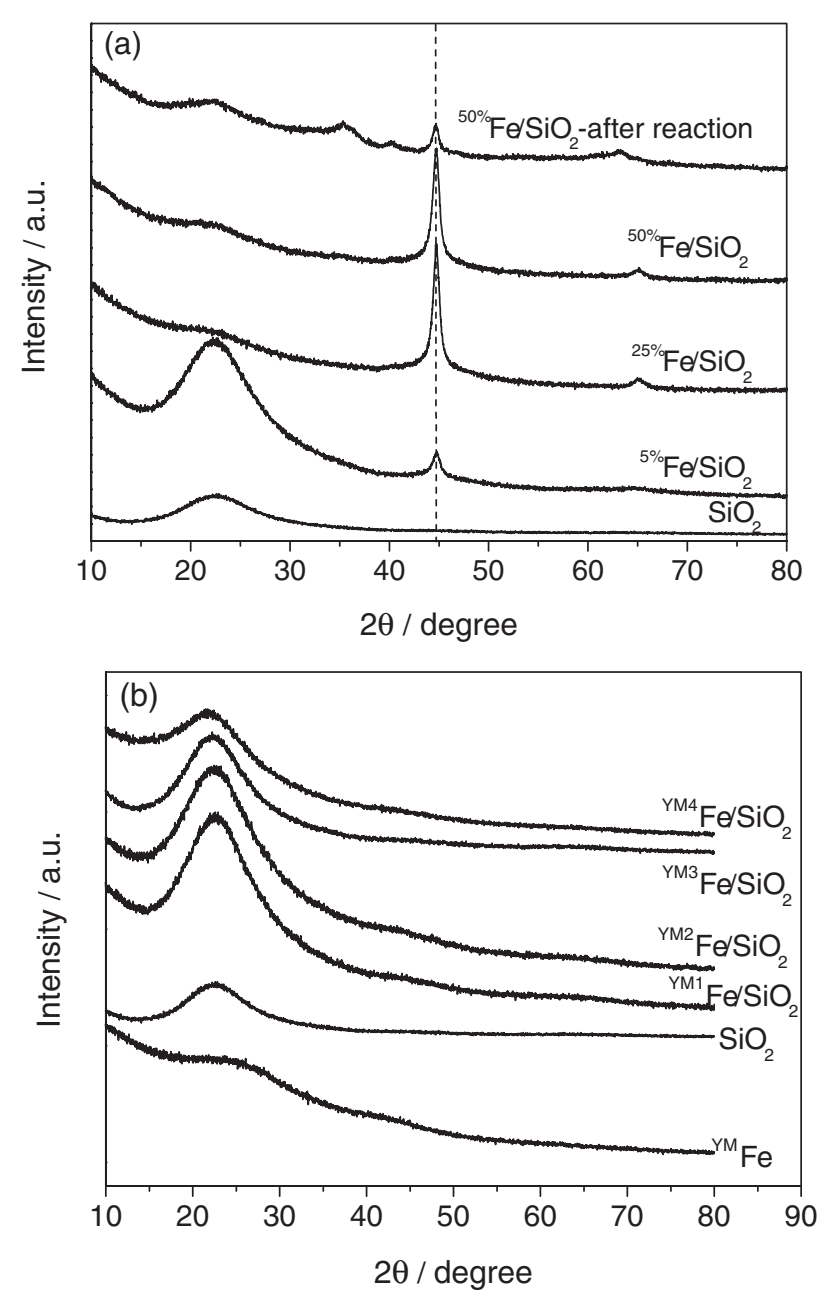

Figure 1. X-Ray diffraction (XRD) patterns of the $\mathrm{Fe} / \mathrm{SiO}_{2}$ catalysts. (a) Prepared with $\mathrm{NaBH}_{4}$; and (b) prepared with yerba mate tea extract.

Table 1. Iron content of the catalysts

\begin{tabular}{lc}
\hline Catalyst & $\mathrm{Fe} / \mathrm{wt} . \%$ \\
\hline${ }^{50 \%} \mathrm{Fe} / \mathrm{SiO}_{2}$ & $45.8^{\mathrm{a}}$ \\
${ }^{25 \%} \mathrm{Fe} / \mathrm{SiO}_{2}$ & $20.9^{\mathrm{a}}$ \\
${ }^{5 \%} \mathrm{Fe} / \mathrm{SiO}_{2}$ & $4.8^{\mathrm{a}}$ \\
${ }^{\mathrm{YM} 1} \mathrm{Fe} / \mathrm{SiO}_{2}$ & $4.3^{\mathrm{b}}$ \\
${ }^{\mathrm{YM} 2} \mathrm{Fe} / \mathrm{SiO}_{2}$ & $10.6^{\mathrm{b}}$ \\
${ }^{\mathrm{YM} 3} \mathrm{Fe} / \mathrm{SiO}_{2}$ & $1.2^{\mathrm{b}}$ \\
${ }^{\mathrm{YM} 4} \mathrm{Fe} / \mathrm{SiO}_{2}$ & $16.2^{\mathrm{b}}$ \\
\hline
\end{tabular}

${ }^{\mathrm{a}}$ Determined by atomic absorption spectroscopy (AAS); ${ }^{\mathrm{b}}$ determined by $\mathrm{X}$-ray fluorescence spectroscopy (FRX).

morphology of the $\mathrm{Fe} / \mathrm{SiO}_{2}$ catalysts prepared using yerba mate tea (Figure 3) present a spherical shape, forming aggregates of amorphous nature, in accordance with the XRD results. Free iron nanoparticles prepared from green tea, black tea, oolong tea ${ }^{33}$ and from eucalyptus leaf extract ${ }^{37}$ presented a similar morphology to ${ }^{\mathrm{YM}} \mathrm{Fe}$ (Figure S7), with the particles reported in the range of 50-100 nm. 

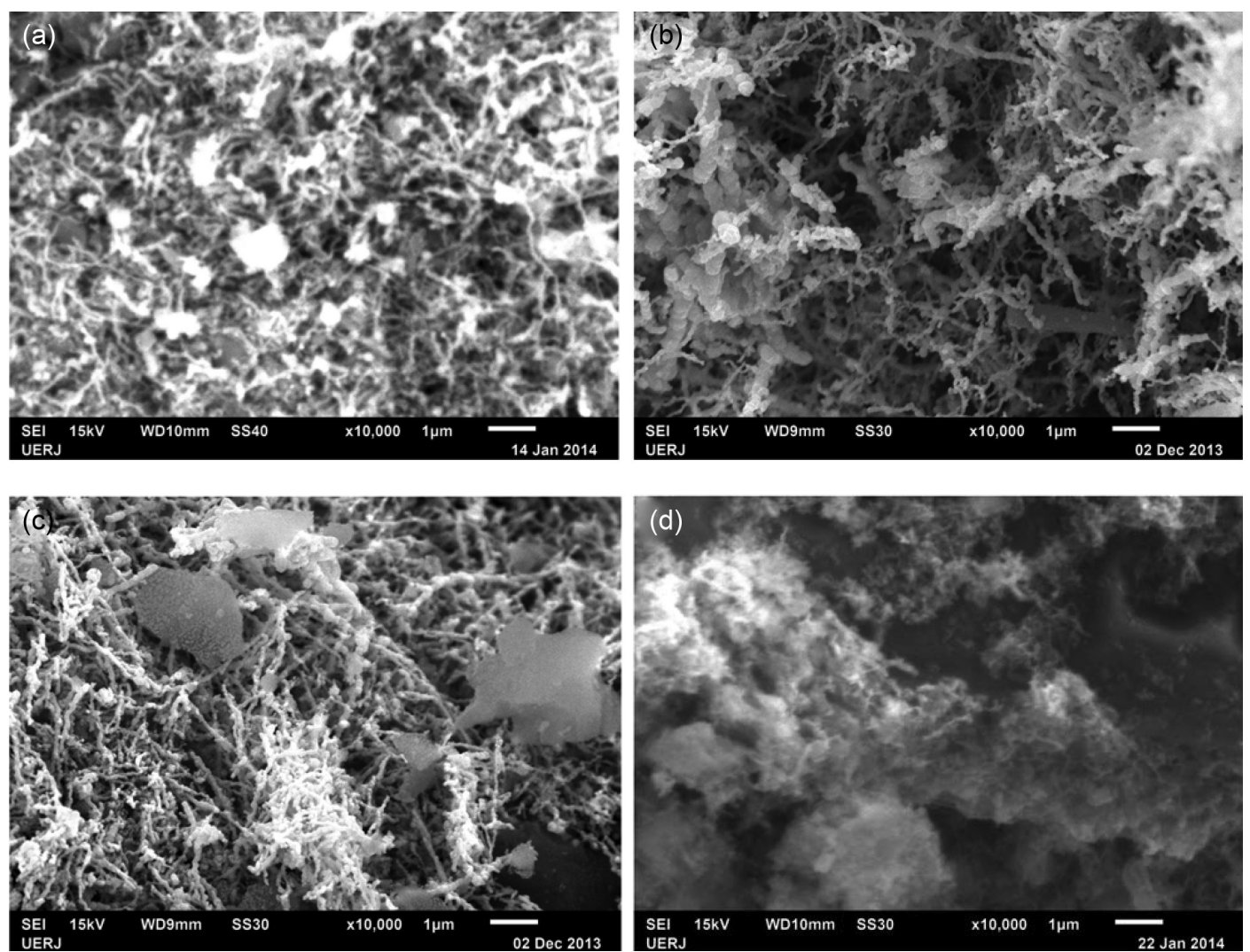

Figure 2. Scanning electron microscopy (SEM) micrographs of the catalysts $(10,000 \times)$. (a) ${ }^{50 \%} \mathrm{Fe} / \mathrm{SiO}_{2} ;$ (b) ${ }^{25 \%} \mathrm{Fe} / \mathrm{SiO}_{2} ;\left(\right.$ c) ${ }^{5 \%} \mathrm{Fe} / \mathrm{SiO}_{2} ;(\mathrm{d}){ }^{50 \%} \mathrm{Fe} / \mathrm{SiO}{ }_{2}$ after reaction.
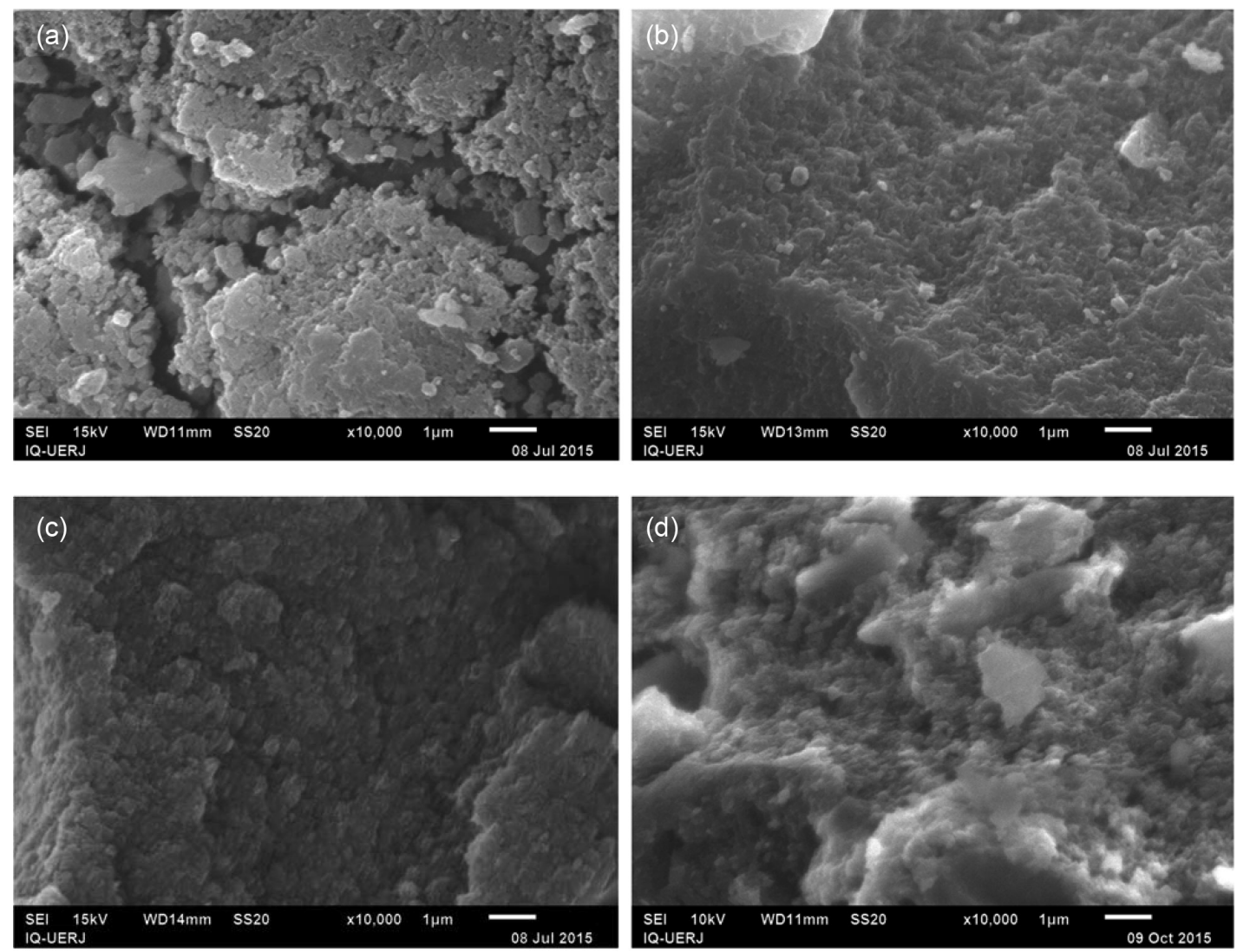

Figure 3. Scanning electron microscopy (SEM) micrographs of the catalysts $(10,000 \times)$. (a) ${ }^{\mathrm{YM} 1} \mathrm{Fe} / \mathrm{SiO}_{2} ;$ (b) ${ }^{\mathrm{YM} 2} \mathrm{Fe} / \mathrm{SiO}_{2} ;(\mathrm{c}){ }^{\mathrm{YM} 3} \mathrm{Fe} / \mathrm{SiO}_{2}$; and $(\mathrm{d}){ }^{\mathrm{YM} 4} \mathrm{Fe} / \mathrm{SiO}_{2}$. 
FTIR spectra (Figure 4) of the catalysts prepared in presence of yerba mate tea were recorded; free nanoparticles ${ }^{\mathrm{YM}} \mathrm{Fe}$ showed characteristic bands of the polyphenolic compounds at $3410 \mathrm{~cm}^{-1}$, assigned to the hydroxyl groups. Vibrations at 2937, 1720, 1520, 1434, 1383,1270 and $1072 \mathrm{~cm}^{-1}$ can be assigned to $\mathrm{C}-\mathrm{H}, \mathrm{C}=\mathrm{O}$, $\mathrm{C}=\mathrm{C}$ and $\mathrm{C}-\mathrm{O}$ stretching, respectively, in agreement with reported iron nanoparticles prepared in presence of tea extracts. ${ }^{21,24}$ The spectra of supported ${ }^{\mathrm{YM}} \mathrm{Fe} / \mathrm{SiO}_{2}$ catalysts showed a combination of bands from the pure silica and the polyphenolic compounds, confirming the capping of the iron nanoparticles by the tea natural products.

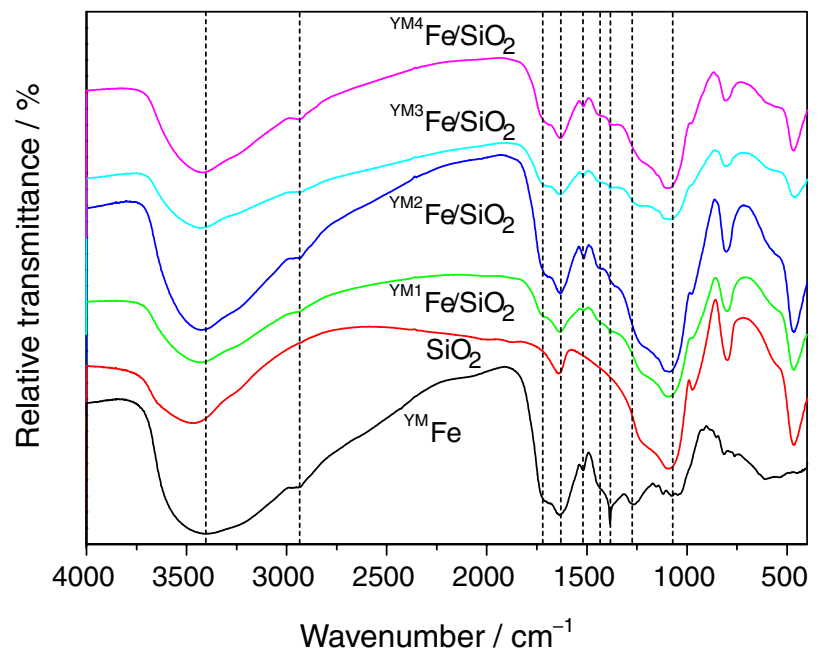

Figure 4. Fourier transform infrared (FTIR) spectra of the $\mathrm{Fe} / \mathrm{SiO}_{2}$ catalysts prepared with yerba mate tea extract.

Thermogravimetric analyses were acquired in order to estimate the amount of organic compounds in the catalysts prepared with yerba mate (Table 2). TGA (Figure 5a) and DTG (Figure 5b) curves comprehend three main regions of weight loss: region I (50 to $120^{\circ} \mathrm{C}$ ) corresponds to water release; region II $\left(120\right.$ to $\left.630{ }^{\circ} \mathrm{C}\right)$ and III $\left(630\right.$ to $\left.900{ }^{\circ} \mathrm{C}\right)$ are assigned to decomposition of organic compounds. 57.7 wt. \% of the free iron nanoparticles ${ }^{\mathrm{YM}} \mathrm{Fe}$ come from organic materials. Among the supported catalysts, ${ }^{\mathrm{YM} 4} \mathrm{Fe} / \mathrm{SiO}_{2}$ presented the highest organic content, followed by ${ }^{\mathrm{YM} 2} \mathrm{Fe} / \mathrm{SiO}_{2},{ }^{\mathrm{YM} 1} \mathrm{Fe} / \mathrm{SiO}_{2}$ and ${ }^{\mathrm{YM} 3} \mathrm{Fe} / \mathrm{SiO}_{2}$. This tendency is in line with the iron content, confirming that the iron nanoparticles are capped by the biomolecules from the tea extract. TGA and DTG curves of the catalysts prepared with $\mathrm{NaBH}_{4}$ showed no considerable decomposition until $1000^{\circ} \mathrm{C}$ (Figure S12), indicating the high thermal stability of the material.

\section{Decolourization of methyl orange}

Decolourization tests were carried out with both classes of catalysts. Firstly, they were tested in the reductive
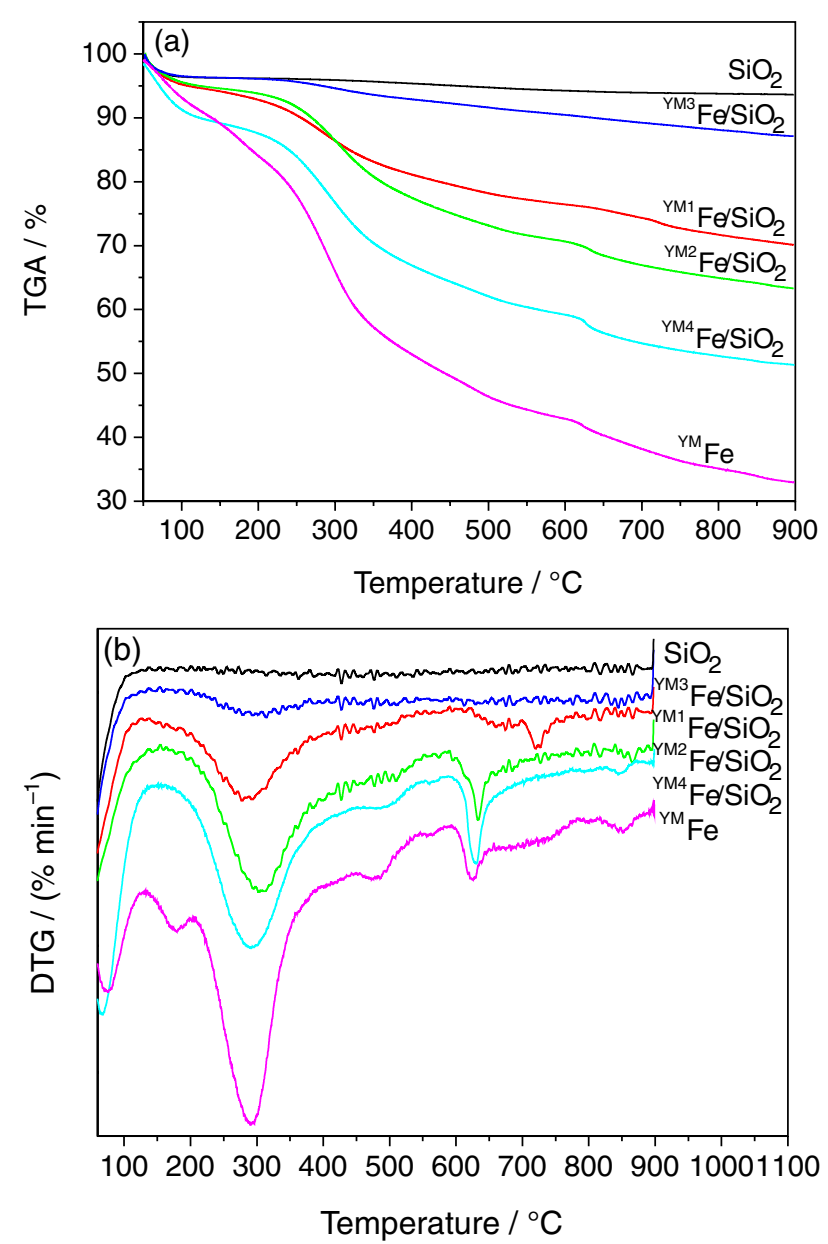

Figure 5. (a) Thermogravimetric (TGA) and (b) derivative thermogravimetric analysis (DTG) curves of the $\mathrm{Fe} / \mathrm{SiO}_{2}$ catalysts prepared with yerba mate tea extract.

degradation of methyl orange and only the catalysts prepared with $\mathrm{NaBH}_{4}$ were active. Then, the catalysts were tested in the heterogeneous Fenton-like system and the catalysts prepared with yerba mate were much more active. The results are discussed bellow.

Tests with the catalysts synthesized using $\mathrm{NaBH}_{4}$

The $\mathrm{Fe} / \mathrm{SiO}_{2}$ catalysts were tested in the reductive degradation of the dye MO. Figure 6a illustrates the UV-Vis spectra during the reaction of $\mathrm{MO}$ and ${ }^{50 \%} \mathrm{Fe} / \mathrm{SiO}_{2}$. It was observed the disappearance of the bands at $\lambda_{\max }=464 \mathrm{~nm}$, assigned to $\mathrm{N}=\mathrm{N}$ bond; and at $\lambda_{\max }=272 \mathrm{~nm}$, assigned to aromatic rings, indicating cleavage of the azo group. Simultaneously, a new band at $\lambda_{\max }=248 \mathrm{~nm}$ appeared, which was attributed to the formation of sulfanilic acid. The complete degradation of MO was achieved in 100 min. GC-MS analysis (Figure S13) showed a single peak, with $\mathrm{m} / z 136$ corresponding to $N, N$-dimethyl-pphenylenodiamine. ESI(+)-MS (Figure S14) analysis showed a peak with $\mathrm{m} / \mathrm{z}$ at 137 and 122 , corresponding 
Table 2. Thermogravimetric analysis data

\begin{tabular}{lcccc}
\hline & \multicolumn{3}{c}{ Weight loss / wt. $\%$} & Organic content / wt. \% \\
\cline { 2 - 4 } Catalyst & $\begin{array}{c}\text { Region I } \\
50-120^{\circ} \mathrm{C}\end{array}$ & $\begin{array}{c}\text { Region II } \\
120-630^{\circ} \mathrm{C}\end{array}$ & $\begin{array}{c}\text { Region III } \\
630-900{ }^{\circ} \mathrm{C}\end{array}$ & - \\
\hline $\mathrm{SiO}_{2}$ & 3.7 & 2.6 & & 24.6 \\
${ }^{\mathrm{YM} 1} \mathrm{Fe} / \mathrm{SiO}_{2}$ & 5.3 & 18.6 & 6.0 & 32.0 \\
${ }^{\mathrm{YM} 2} \mathrm{Fe} / \mathrm{SiO}_{2}$ & 4.6 & 24.5 & 7.5 & 3.0 \\
${ }^{\mathrm{YM} 3} \mathrm{Fe} / \mathrm{SiO}_{2}$ & 3.6 & 6.2 & 3.0 & 38.0 \\
${ }^{\mathrm{YM} 4} \mathrm{Fe} / \mathrm{SiO}_{2}$ & 10.6 & 29.9 & 10.1 & 57.7 \\
${ }^{\mathrm{YM}} \mathrm{Fe}$ & 9.3 & 47.6 & & \\
\hline
\end{tabular}

to $N, N$-dimethyl- $p$-phenylenodiamine, while ESI(-)-MS showed the peak at $\mathrm{m} / z .172$ corresponding to sulfanilic acid (Figure S15).

The experimental data were fitted by first-order and second-order kinetic models, as shown in Figure 7a. The obtained parameters were better for first-order model,
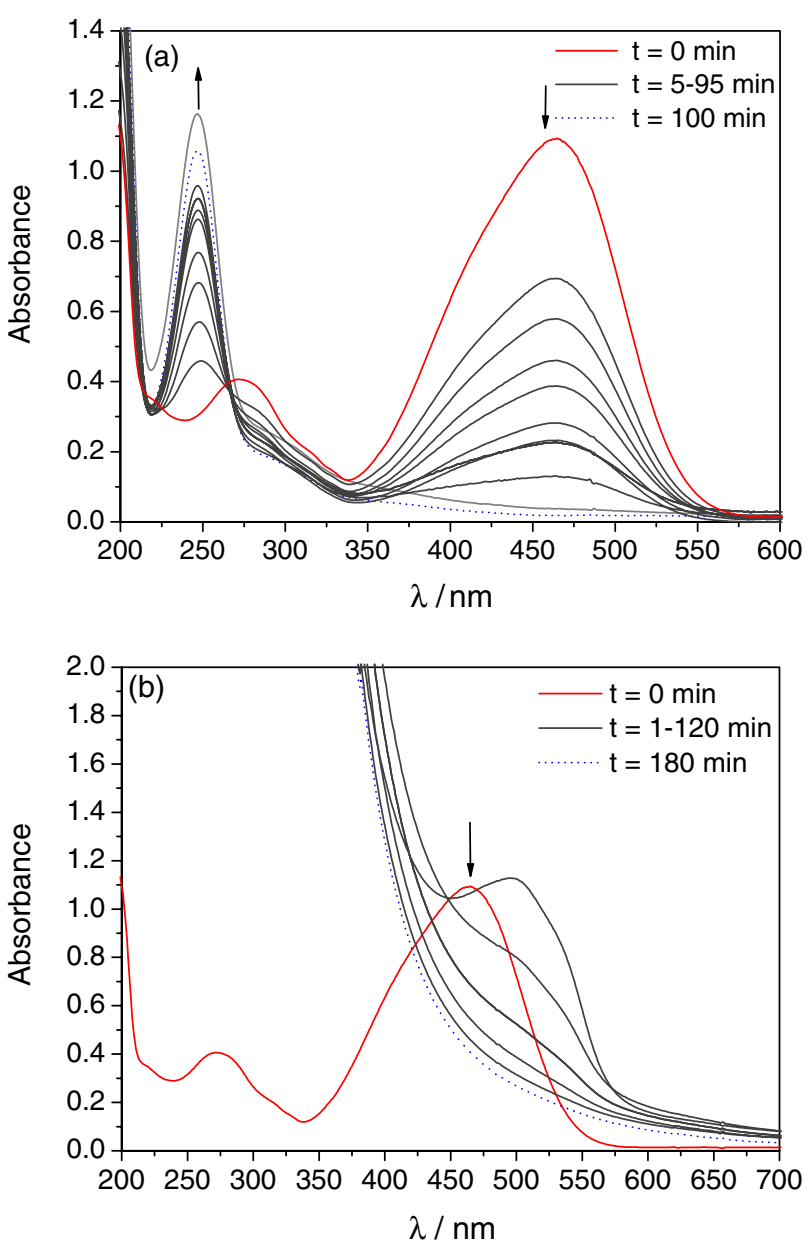

Figure 6. Ultraviolet-visible (UV-Vis) spectra of methyl orange $\left(5.0 \times 10^{-5} \mathrm{~mol} \mathrm{~L}^{-1}\right)$ degradation at $25{ }^{\circ} \mathrm{C}, \mathrm{pH} 5.0$, with (a) ${ }^{50 \%} \mathrm{Fe} / \mathrm{SiO}_{2}$ $(132.0 \mathrm{mg})$; and (b) ${ }^{\mathrm{YM} 2} \mathrm{Fe} / \mathrm{SiO}_{2}(40.0 \mathrm{mg}), \mathrm{H}_{2} \mathrm{O}_{2}\left(0.56 \mathrm{~mol} \mathrm{~L}^{-1}\right)$. The arrows indicate the direction of the band variation. in accordance with related studies. The corresponding $k=9.1 \times 10^{-2} \mathrm{~min}^{-1}$ was consistent with the value found for the Fenton system $\mathrm{Fe}^{2+} / \mathrm{H}_{2} \mathrm{O}_{2} /$ acid black I $\left(k=5.56 \times 10^{-2} \mathrm{~min}^{-1}\right) .^{38}$

The reaction was investigated at different conditions; the initial screening experiments were carried out with the
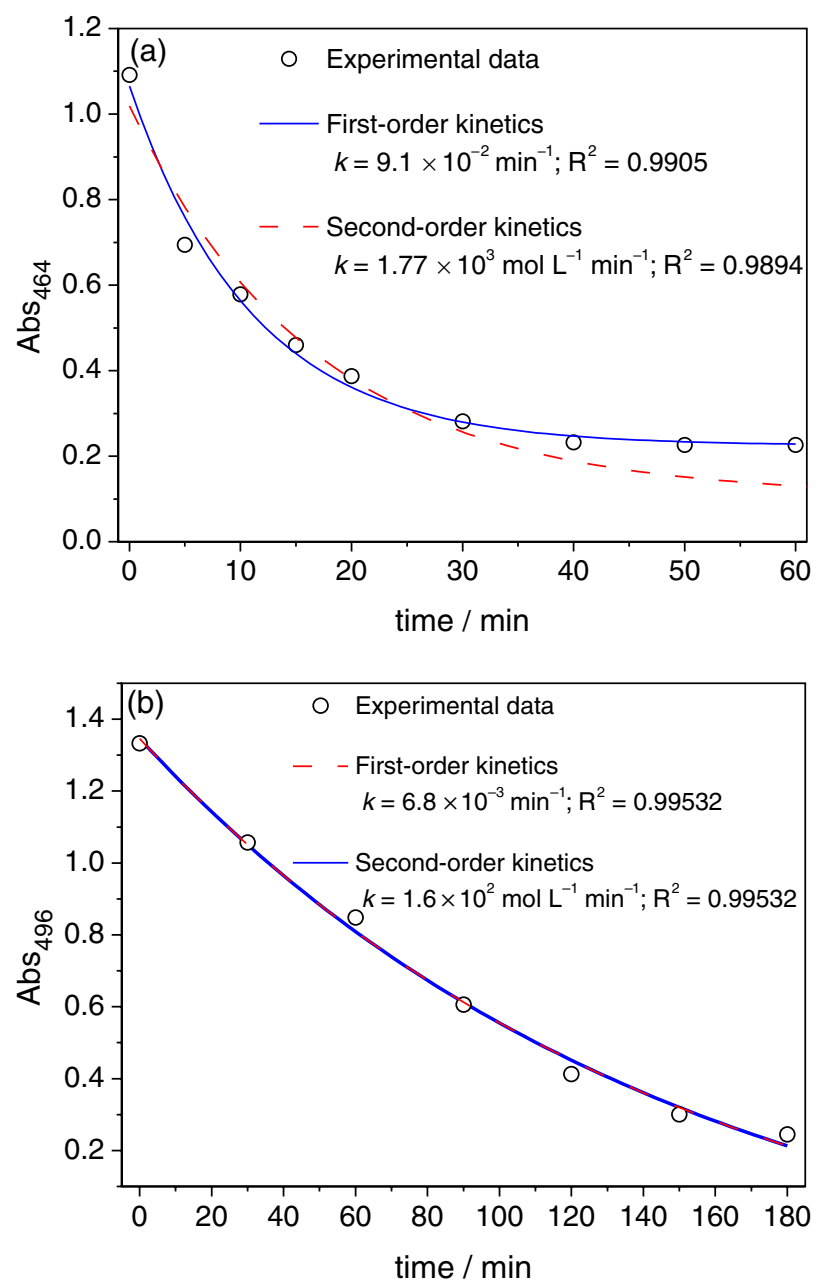

Figure 7. Kinetics first and second order fits of the time trace of methyl orange degradation $\left(5.0 \times 10^{-5} \mathrm{~mol} \mathrm{~L}^{-1}\right)$ at $25^{\circ} \mathrm{C}$ and $\mathrm{pH} 5.0$, with (a) ${ }^{50 \%} \mathrm{Fe} / \mathrm{SiO}_{2}(132.0 \mathrm{mg})$; and (b) ${ }^{\mathrm{YM} 2} \mathrm{Fe} / \mathrm{SiO}_{2}(40.0 \mathrm{mg}), \mathrm{H}_{2} \mathrm{O}_{2}\left(0.56 \mathrm{molL}^{-1}\right)$. 
catalyst ${ }^{50 \%} \mathrm{Fe} / \mathrm{SiO}_{2}$. Parameters such as catalyst dosage, iron content, $\mathrm{pH}$, temperature and reaction time were investigated, as discussed later. Control experiments with silica gel showed only $1.6 \%$ of maximum decolourization, while the catalyst ${ }^{50 \%} \mathrm{Fe} / \mathrm{SiO}_{2}$ reached $95 \%$ at the same condition. On the other hand, free iron(0) nanoparticles reached only $65.5 \%$ of maximum decolourization, at a smaller reaction rate, due to the lower surface area and consequently less active sites available to react.

The effect of catalyst mass was verified from $6 \mathrm{mg}$ $($ Fe: $\mathrm{MO}$ molar ratio $=8.54)$ to $220 \mathrm{mg}(\mathrm{Fe}: \mathrm{MO}$ molar ratio $=284$ ), at $\mathrm{pH} 5.0$ and $25{ }^{\circ} \mathrm{C}$. Figure $8 \mathrm{a}$ shows the maximum degradation $v s$. catalyst mass, which increased until $88 \mathrm{mg}(\mathrm{Fe}: \mathrm{MO}$ molar ratio $=125)$, and beyond this point there was a saturation region, where the number of available catalytic sites were enough to react with all dye. Besides that, the diffusion is very important in heterogeneous catalysis once the dye needs to be adsorbed on the catalyst surface beforehand, and this step can limit the reaction rate. In theory, $6 \mathrm{mg}{ }^{50 \%} \mathrm{Fe} / \mathrm{SiO}_{2}$ should be enough to degrade the
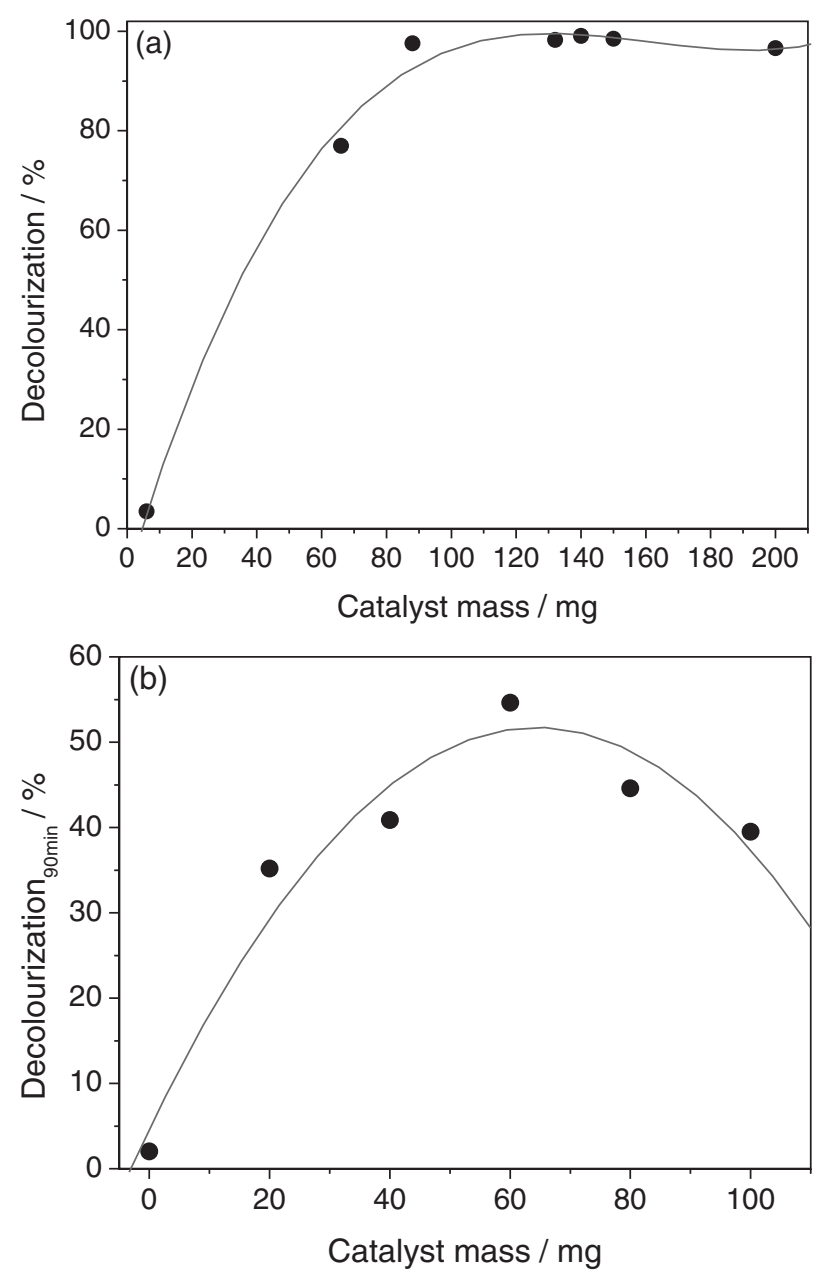

Figure 8. Maximum decolourization of methyl orange $\left(5.0 \times 10^{-5} \mathrm{~mol} \mathrm{~L}^{-1}\right)$ vs. catalyst mass, at $25^{\circ} \mathrm{C}, \mathrm{pH} 5.0$, catalyzed by (a) ${ }^{50 \%} \mathrm{Fe} / \mathrm{SiO}_{2}$; and (b) ${ }^{\mathrm{YM} 2} \mathrm{Fe} / \mathrm{SiO}_{2}, \mathrm{H}_{2} \mathrm{O}_{2}\left(0.56 \mathrm{~mol} \mathrm{~L}^{-1}\right)$. azo bond since the Fe:MO molar ratio is 8.4, and each MO molecule needs four electrons to be reduced. However, with $50 \mathrm{wt} . \%$ of iron, only a fraction of the iron( $(0)$ is at the catalyst surface and consequently available to react.

Methyl orange degradation was carried out at different initial $\mathrm{pH}$ values (Table 3). The $\mathrm{pH}$ of $5.0 \times 10^{-5} \mathrm{~mol} \mathrm{~L}^{-1}$ $\mathrm{MO}$ aqueous solution is 5.0, where the first-order constant was $k=0.091 \mathrm{~min}^{-1}$. At acidic $\mathrm{pH} 2.8$, the constant was $k=0.70 \mathrm{~min}^{-1}$ and at basic $\mathrm{pH} 9.9$ the constant was $k=0.44 \mathrm{~min}^{-1}$, showing that the degradation of MO occurs in a large range of $\mathrm{pH}$ values, but at higher rate at acidic $\mathrm{pH}$. These results are in agreement with the literature where the MO decolourization by free zero-valent iron nanoparticles can occur without addition of acid, base or buffer, although at a higher rate at lower pHs. ${ }^{39}$

Table 3. Effect of $\mathrm{pH}$ in the decolourization of methyl orange with ${ }^{50 \%} \mathrm{Fe} / \mathrm{SiO}_{2}(132.0 \mathrm{mg})$ at $25^{\circ} \mathrm{C}$

\begin{tabular}{lcc}
\hline $\mathrm{pH}$ & $\begin{array}{c}\text { Maximum } \\
\text { decolourization } / \%\end{array}$ & $k / \mathrm{min}^{-1}$ \\
\hline 2.5 & 98.8 & 0.52 \\
2.8 & 98.3 & 0.70 \\
5.0 & 98.3 & 0.091 \\
8.2 & 97.7 & 0.22 \\
9.9 & 97.2 & 0.44 \\
\hline
\end{tabular}

Figure 9 shows the recycle of ${ }^{50 \%} \mathrm{Fe} / \mathrm{SiO}_{2}$ at $25{ }^{\circ} \mathrm{C}$, the catalyst remained active for 3 cycles; after that, the decolourization had decreased from 95.1 to $32.7 \%$ in the fourth cycle. The catalyst recycle efficiency was higher than the reported for similar catalysts, ${ }^{19}$ where only two cycles could be carried out without activity loss. A treatment with a reducing agent such as $\mathrm{NaBH}_{4}$ can also increase the catalyst

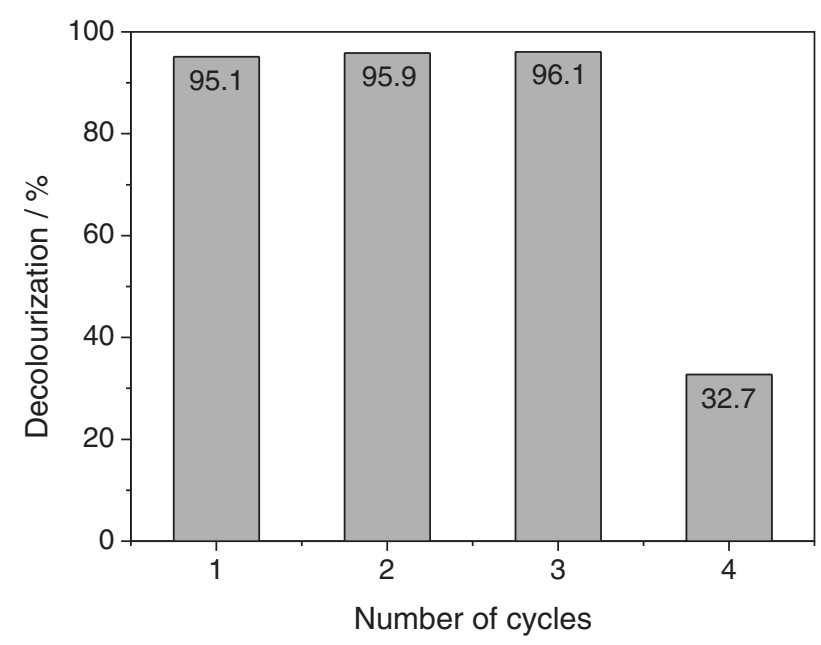

Figure 9. Recycle of the ${ }^{50 \%} \mathrm{Fe} / \mathrm{SiO}_{2}$ catalyst $(40 \mathrm{mg}$ ) in methyl orange $\left(5.0 \times 10^{-5} \mathrm{~mol} \mathrm{~L}^{-1}, 30 \mathrm{~mL}\right)$ degradation at $25^{\circ} \mathrm{C}, \mathrm{pH} 5.0$. 
lifetime,${ }^{10}$ running up to five cycles without lost of activity. XRD analysis of the catalyst after one cycle of reaction (Figure 1a) showed formation of maghemite $\left(\mathrm{Fe}_{2} \mathrm{O}_{3}\right)$ at $2 \theta=35.68^{\circ}$, although an intense peak of iron $(0)$ is still present. The iron content after the reaction determined by AAS, $46.1 \mathrm{wt} . \%$, did not decrease in comparison with the starting catalyst, $45.8 \mathrm{wt} . \%$, indicating that no significant leaching of iron occurred. SEM micrograph (Figures $2 \mathrm{~d}$ and S6) showed more dispersed, smaller particles.

The reaction temperature was varied from 25 to $40{ }^{\circ} \mathrm{C}$ (Table 4); the maximum degradation was not affected, however, the reaction rate increased with temperature, as expected.

Table 4. Temperature effect in methyl orange degradation with $132 \mathrm{mg}$ of ${ }^{50 \%} \mathrm{Fe} / \mathrm{SiO}_{2}$ and $100 \mathrm{~mL}$ of $5.0 \times 10^{-5} \mathrm{~mol} \mathrm{~L}^{-1}$ dye solution

\begin{tabular}{lcc}
\hline Temperature $/{ }^{\circ} \mathrm{C}$ & $\begin{array}{c}\text { Maximum } \\
\text { decolourization } / \%\end{array}$ & $k / \mathrm{min}^{-1}$ \\
\hline 25 & 95.7 & 0.091 \\
30 & 97.2 & 1.1 \\
40 & 97.8 & 1.4 \\
\hline
\end{tabular}

Three catalysts with different iron contents were prepared and tested in MO decolourization, at $30^{\circ} \mathrm{C}$, pH 5.0, with $132 \mathrm{mg}$ of catalyst, as shown in Table 5. The maximum decolourization of $\mathrm{MO}$ was quite similar for ${ }^{50 \%} \mathrm{Fe} / \mathrm{SiO}_{2}$ and ${ }^{25 \%} \mathrm{Fe} / \mathrm{SiO}_{2}$, although the first was 8 -folds faster than the second. ${ }^{5 \%} \mathrm{Fe} / \mathrm{SiO}_{2}$ achieved only $16.9 \%$ of maximum decolourization, which can be explained by its lower Fe:MO ratio and, consequently, the iron(0) in the catalyst surface were not enough to degrade all dye. Even though, the catalyst ${ }^{5 \%} \mathrm{Fe} / \mathrm{SiO}_{2}$ was faster than ${ }^{25 \%} \mathrm{Fe} / \mathrm{SiO}_{2}$, probably due to the higher dispersion of the nanoparticles over the support surface.

Table 5. Iron loading effect in methyl orange (MO) degradation at $30^{\circ} \mathrm{C}$, $100 \mathrm{~mL}$ of $5.0 \times 10^{-5} \mathrm{~mol} \mathrm{~L}^{-1}$ solution and $132.0 \mathrm{mg}$ of catalyst

\begin{tabular}{lccc}
\hline Catalyst & Fe:MO & $\begin{array}{c}\text { Maximum } \\
\text { decolourization } / \%\end{array}$ & $k / \mathrm{min}^{-1}$ \\
\hline${ }^{50 \%} \mathrm{Fe} / \mathrm{SiO}_{2}$ & 216 & 97.2 & 1.2 \\
${ }^{25 \%} \mathrm{Fe} / \mathrm{SiO}_{2}$ & 99 & 97.3 & 0.16 \\
${ }^{5 \%} \mathrm{Fe} / \mathrm{SiO}_{2}$ & 24 & 16.9 & 0.26 \\
\hline
\end{tabular}

Indigo carmine, crystal violet and methylene blue were also tested with ${ }^{50 \%} \mathrm{Fe} / \mathrm{SiO}_{2}$ in order to verify the efficiency of the catalyst toward different dyes. The catalyst was not able to degrade methylene blue; however, $94.7 \%$ of degradation was obtained for indigo carmine at $k=7.0 \mathrm{~min}^{-1}$, and $99.6 \%$ of degradation for crystal violet at $k=0.86 \mathrm{~min}^{-1}$.
The degradation reactions were also tested at heterogeneous Fenton-like conditions, with addition of hydrogen peroxide after the completion of the reduction step as well as in the beginning of the reaction, and no improvement in $\mathrm{MO}$ degradation was observed in both cases. At MO: $\mathrm{H}_{2} \mathrm{O}_{2}$ molar ratio of $1: 10^{4}$ at $\mathrm{pH} 5.0$, only $41.2 \%$ of degradation was obtained. At MO: $\mathrm{H}_{2} \mathrm{O}_{2}$ molar ratio of $1: 10^{6}$, 69.1 and $56.2 \%$ were obtained at $\mathrm{pH} 5.0$ and 2.6, respectively.

Tests with the catalysts synthesized using yerba mate tea extract

Unlike the catalysts prepared with $\mathrm{NaBH}_{4}$, the nanoparticles prepared using yerba mate tea were not active for the reductive degradation of $\mathrm{MO}$, due to the absence of iron(0) in the catalysts. On the other hand, these catalysts were very active in the Fenton-like chemistry. UV-Vis spectra (Figure 6b) show the shift of the MO band from $\lambda_{\max }=464$ to $496 \mathrm{~nm}$ right after mixing of the dye with the catalyst and $\mathrm{H}_{2} \mathrm{O}_{2}$, which can be explained by the $\mathrm{pH}$ drop from 5.0 to 4.0 and finally, to 3.5 , after the catalyst and $\mathrm{H}_{2} \mathrm{O}_{2}$ addition, respectively, probably caused by proton transfer to the dye, indicating the acidic character of the catalyst. Another characteristic of the electronic spectra is the strong absorption of $\mathrm{H}_{2} \mathrm{O}_{2}$ in the UV region, presenting a tail until $700 \mathrm{~nm}$. As consequence, some MO bands cannot be followed and the band at $\lambda_{\max }=496 \mathrm{~nm}$ does not reach absorbance zero even after the complete degradation of the dye. GC-MS and ESI-MS analyses did not show any peak of degradation products of MO, which can suggest the successive oxidation to mineralization or formation of small molecules. ${ }^{40}$

Figure $7 \mathrm{~b}$ shows the fitting of the experimental data with first and second-order kinetic models, both were well suited to the acquired data. The first order kinetic constant $k=6.8 \times 10^{-3} \mathrm{~min}^{-1}$ was one order of magnitude lower than the value reported for the Fenton system $\mathrm{Fe}^{2+} / \mathrm{H}_{2} \mathrm{O}_{2} /$ acid black $\mathrm{I}\left(k=5.56 \times 10^{-2} \mathrm{~min}^{-1}\right),{ }^{38}$ and also lower than the value found for the reductive degradation of MO with the nanoparticles prepared by $\mathrm{NaBH}_{4}$.

The MO degradation was investigated in different conditions; the initial screening experiments were carried out with the catalyst ${ }^{\mathrm{YM} 2} \mathrm{Fe} / \mathrm{SiO}_{2}$. Parameters such as $\mathrm{H}_{2} \mathrm{O}_{2}$ concentration, catalyst mass, iron content, $\mathrm{pH}$, temperature and reaction time were investigated.

Firstly, the MO: $\mathrm{H}_{2} \mathrm{O}_{2}$ ratio was screened; Figure 10a shows the degradation over time at different initial concentrations of $\mathrm{H}_{2} \mathrm{O}_{2}$. Degradation increases as the reaction proceeds, reaching around $80 \%$ of decolourization after 180 min with $1.12 \mathrm{~mol} \mathrm{~L}^{-1}$ of $\mathrm{H}_{2} \mathrm{O}_{2}$, which corresponds to a $\mathrm{MO}: \mathrm{H}_{2} \mathrm{O}_{2}$ ratio of 1:22400. Beyond this proportion the degradation did not increase, as evidenced in Figure 10b for $90 \mathrm{~min}$ of reaction. This is due to the scavenging effect 
of hydroxyl radicals, which at high concentration of $\mathrm{H}_{2} \mathrm{O}_{2}$ generates less reactive radicals as $\mathrm{HO}_{2}$, the same effect was described for iron nanoparticles prepared with green tea and applied in monochlorobenzene degradation. ${ }^{41}$ Control experiments without $\mathrm{H}_{2} \mathrm{O}_{2}$ showed no decolourization, indicating that the absorption of the dye over the catalyst is negligible under the reaction conditions.
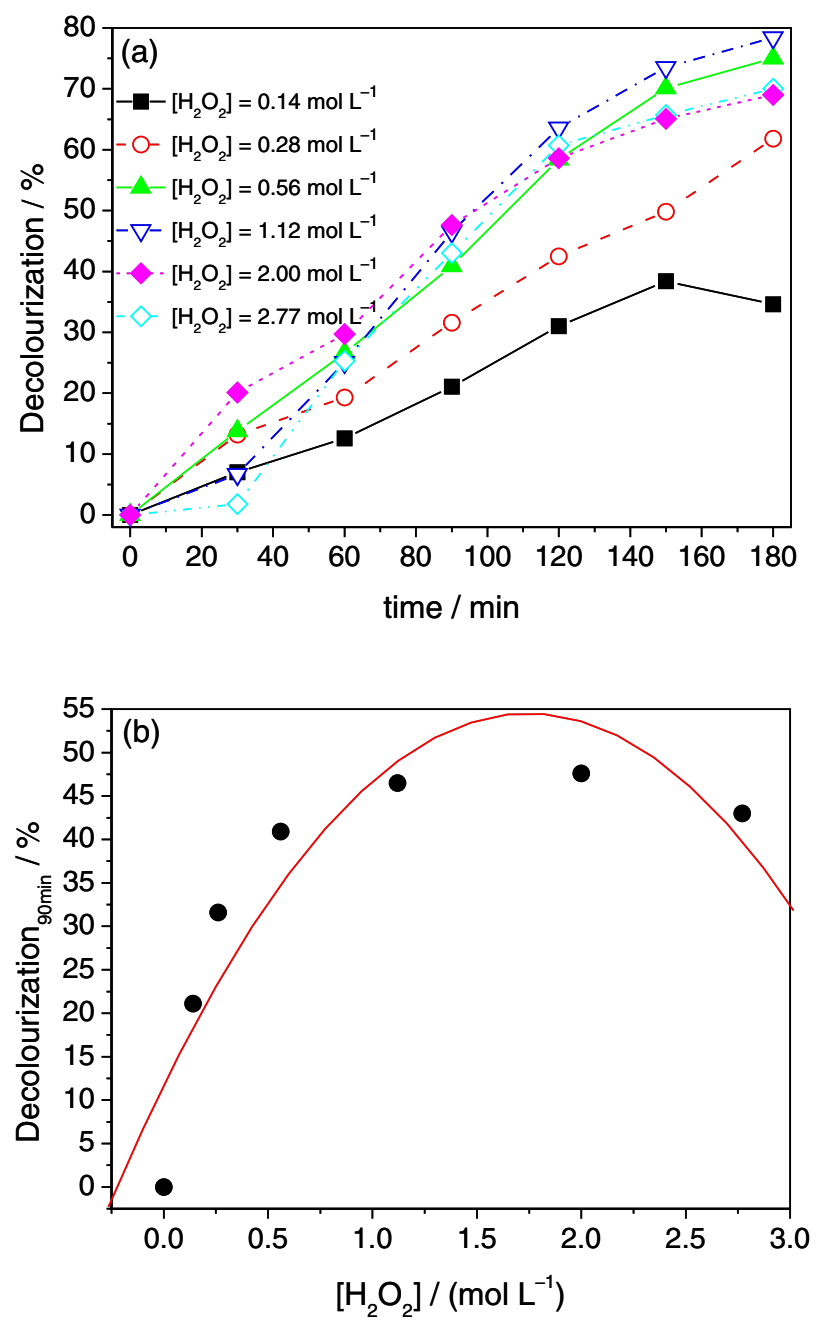

Figure 10. Decolourization of methyl orange $\left(5.0 \times 10^{-5} \mathrm{~mol} \mathrm{~L}^{-1}\right)$ at different concentrations of $\mathrm{H}_{2} \mathrm{O}_{2}$ using $40 \mathrm{mg}$ of ${ }^{\text {YM2 }} \mathrm{Fe} / \mathrm{SiO}_{2}$ at $25^{\circ} \mathrm{C}$ and $\mathrm{pH}$ 3.5. (a) Decolourization $v s$. reaction time; and (b) decolourization at 90 min vs. $\mathrm{H}_{2} \mathrm{O}_{2}$ concentration $\left(\left[\mathrm{H}_{2} \mathrm{O}_{2}\right]\right)$.

The effect of catalyst mass in MO degradation was verified with ${ }^{\mathrm{YM} 2} \mathrm{Fe} / \mathrm{SiO}_{2}$, from a mass of $20.0 \mathrm{mg}$ ( $\mathrm{Fe}: \mathrm{MO}$ molar ratio $=29)$ to $100.0 \mathrm{mg}(\mathrm{Fe}: \mathrm{MO}$ molar ratio $=147)$. Figure $8 \mathrm{~b}$ shows the decolourization $v s$. catalyst mass, after $90 \mathrm{~min}$ of reaction. The dye degradation increased until $60.0 \mathrm{mg}(\mathrm{Fe}: \mathrm{MO}$ molar ratio $=88)$, and after this point a slight decrease was observed, probably due to degradation of $\mathrm{H}_{2} \mathrm{O}_{2}$ that competes with the generation of hydroxyl radicals when iron concentration is high, as described for green iron nanoparticles in the degradation of monochlorobenzene..$^{41}$ At 180 min of reaction, all amounts of catalyst tested reached around $75 \%$ of decolourization.

Figure 11 shows the degradation of MO at different initial $\mathrm{pH}$ values, where it is possible to observe that the reaction was much faster at acidic solution, as described in literature for Fenton system, in which the optimum $\mathrm{pH}$ is around $3 .^{41,42}$ The initial $\mathrm{pH}$ values were measured in the beginning of the reaction after the addition of the catalyst and $\mathrm{H}_{2} \mathrm{O}_{2}$; at neutral conditions, the initial $\mathrm{pH}$ drops from 5.0 to 4.0 after the catalyst addition, and to 3.5 after $\mathrm{H}_{2} \mathrm{O}_{2}$ addition, which suggests the acidic character of the catalyst, as reported for similar iron compounds. ${ }^{43}$ At acidic and basic conditions, the adjustment with $\mathrm{HCl}$ or $\mathrm{NaOH}$ was carried out in presence of the catalyst and the initial value was measured right after $\mathrm{H}_{2} \mathrm{O}_{2}$ addition as the reaction started. A maximum degradation of $76 \%$ was achieved at neutral $\mathrm{pH}$ (3.5), $63 \%$ at acidic $\mathrm{pH}(2.4)$; however, at basic $\mathrm{pH}$ (10.5) only $41 \%$ was decolourized after $180 \mathrm{~min}$. Besides that, at $30 \mathrm{~min}$ of reaction, the maximum decolourization has been already reached at acidic $\mathrm{pH}$, while for the other $\mathrm{pHs}$ it took much longer (180 min). The $\mathrm{pH}$ measured at the end of the reaction was 2.7, 2.8 and 10.2 , for neutral, acidic and basic conditions, respectively.

The degradation was also followed in different temperatures and it was possible to observe that the reaction rate increases considerably from 25 to $60{ }^{\circ} \mathrm{C}$ (Figure 12). After $25 \mathrm{~min}$ of reaction, the degradation has reached $70 \%$ at $50{ }^{\circ} \mathrm{C}$ against $25 \%$ at $25{ }^{\circ} \mathrm{C}$. The same effect was observed for the free iron nanoparticles prepared with green tea, where $64 \%$ of degradation of monochlorobenzene was reached at $40{ }^{\circ} \mathrm{C}$ against $32 \%$ at $25^{\circ} \mathrm{C}$ at the same time..$^{41}$

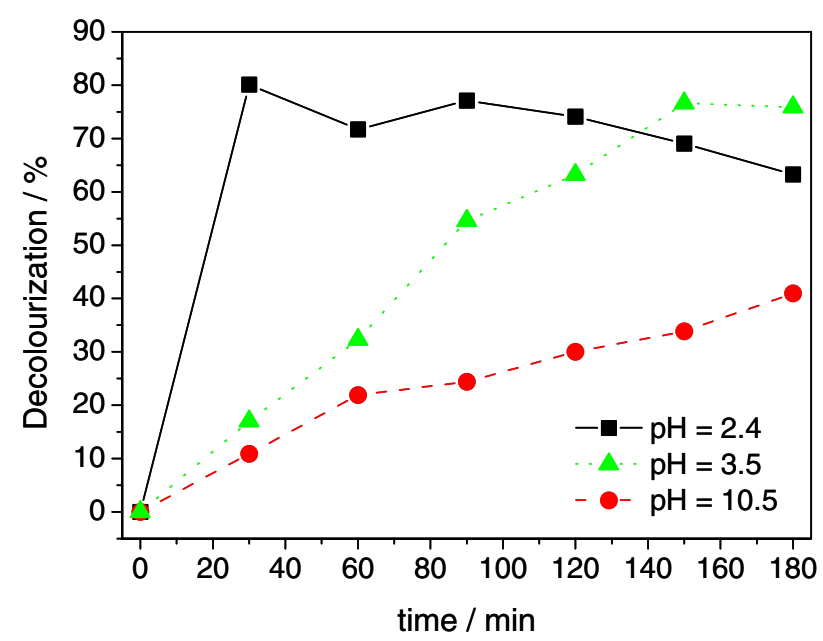

Figure 11. Decolourization of methyl orange $\left(5.0 \times 10^{-5} \mathrm{~mol} \mathrm{~L}^{-1}\right)$ at different initial $\mathrm{pH}$ values using $60 \mathrm{mg}$ of ${ }^{\mathrm{YM} 2} \mathrm{Fe} / \mathrm{SiO}_{2}$ and $\mathrm{H}_{2} \mathrm{O}_{2}$ $\left(0.56 \mathrm{~mol} \mathrm{~L}^{-1}\right)$ at $25^{\circ} \mathrm{C}$.

The comparison of the different catalysts is shown in Figure 13; they were more active than pure $\mathrm{SiO}_{2}$, which 


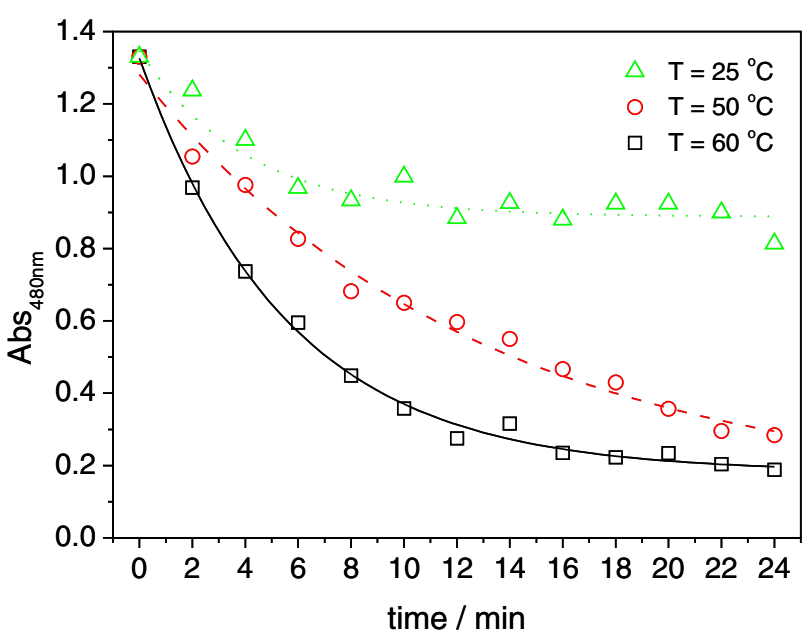

Figure 12. Time trace of methyl orange degradation $\left(5.0 \times 10^{-5} \mathrm{~mol} \mathrm{~L}^{-1}\right)$ with ${ }^{\mathrm{YM} 3} \mathrm{Fe} / \mathrm{SiO}_{2}$ at $\mathrm{pH} 5.0$ at different temperatures (T).

presented a decolourization around $20 \%$. The catalysts ${ }^{\mathrm{YM}}{ }_{1} \mathrm{Fe} / \mathrm{SiO}_{2}$ and ${ }^{\mathrm{YM}}{ }_{3} \mathrm{Fe} / \mathrm{SiO}_{2}$ were slightly more efficient than ${ }^{\mathrm{YM}}{ }^{2} \mathrm{Fe} / \mathrm{SiO}_{2}$, although they presented lower iron contents. This suggests that more active sites can favor side degradation of $\mathrm{H}_{2} \mathrm{O}_{2}$ to $\mathrm{O}_{2}$, then disfavoring the formation of the active hydroxyl radicals. Lower iron content can also favor the formation of smaller and more active nanoparticles. On the other hand, ${ }^{\mathrm{YM} 2} \mathrm{Fe} / \mathrm{SiO}_{2}$ and ${ }^{\mathrm{YM} 4} \mathrm{Fe} / \mathrm{SiO}_{2}$ presented similar activities, even comparable to ${ }^{\mathrm{YM}} \mathrm{Fe}$, indicating that the support did not diminish the efficiency of the free iron nanoparticles. The main advantage of using $\mathrm{SiO}_{2}$ as support is the possibility of recycling the catalyst after reaction and then minimizing the formation of residual iron slurry. Unfortunately, in our case, the attempts to recycle the catalyst were unsuccessful once it was oxidized during the reaction, with the color changed from black to brown, and the activity decreased to half in the second cycle.

Indigo carmine, crystal violet and methylene blue where also tested with ${ }^{\mathrm{YM} 2} \mathrm{Fe} / \mathrm{SiO}_{2}(60.0 \mathrm{mg})$ under Fentonlike conditions, with degradation of 75,57 and $89 \%$, respectively, in $150 \mathrm{~min}$ of reaction.

\section{Conclusions}

Iron nanoparticles supported in silica gel were prepared by a green method using the polyphenolic-rich extract of the plant yerba mate and successfully applied in degradation of pollutant dyes. It was possible to correlate the amount of organic materials caped to the nanoparticles with the iron content, which varied according to the synthesis conditions. Besides that, the iron nanoparticles were amorphous due to the functionalization by the polyphenols. A comparison with the zero-valent iron nanoparticles prepared by the classical method using $\mathrm{NaBH}_{4}$ as reducing agent showed that the
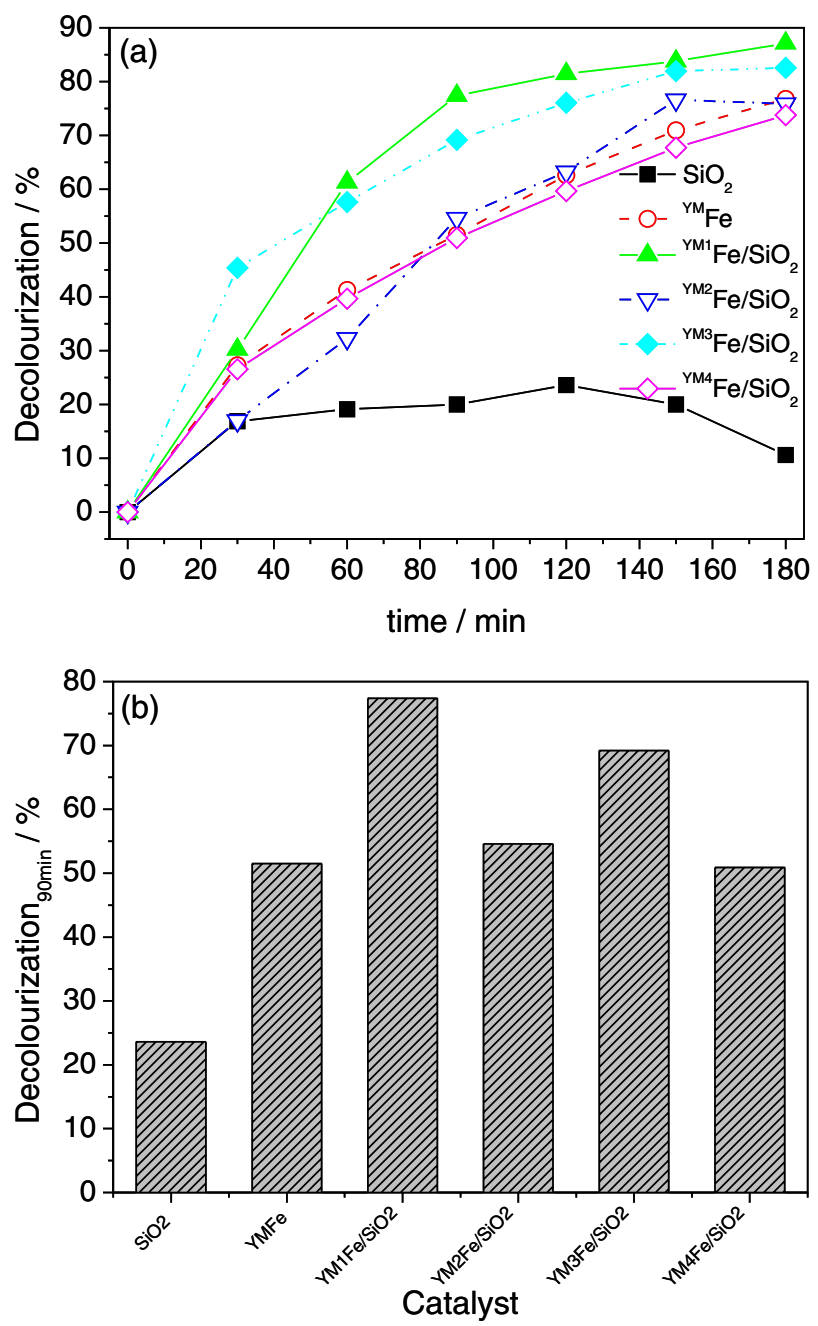

Figure 13. Decolourization of methyl orange $\left(5.0 \times 10^{-5} \mathrm{~mol} \mathrm{~L}^{-1}\right)$ with different catalysts $(60 \mathrm{mg})$ and $\mathrm{H}_{2} \mathrm{O}_{2}\left(0.56 \mathrm{~mol} \mathrm{~L}^{-1}\right)$ at $25^{\circ} \mathrm{C}$ and $\mathrm{pH} 3.5$. (a) Decolourization vs. reaction time; and (b) decolourization at $90 \mathrm{~min}$ vs. catalyst.

catalysts differed in the oxidation state of the iron composites, being the green catalysts mainly constituted of iron oxides. Both types of catalysts were effective in the degradation of the azo dye methyl orange, as the catalysts prepared with $\mathrm{NaBH}_{4}$ acted in the reductive degradation, and the green catalysts were efficient in the heterogeneous Fenton system.

\section{Supplementary Information}

Supplementary information (SEM micrographs and chromatograms) is available free of charge at http://jbcs.sbq.org.br

\section{Acknowledgments}

We acknowledge CNPq (459256/2014-9 Universal 2014) and FAPERJ (E-26/111.377/2014 APQ1 2014/01 
and E-26/202.859/2015 Jovem Cientista do Nosso Estado 2015) for supporting this project. We acknowledge Prof Marcelo M. Pereira (IQ-UFRJ) for the XRD and TGA/DTG analysis.

\section{References}

1. Chahbane, N.; Popescu, D.-L.; Mitchell, D. A.; Chanda, A.; Lenoir, D.; Ryabov, A. D.; Schramma, K.-W.; Collins, T. J.; Green Chem. 2007, 9, 49.

2. Gottlieb, A.; Shaw, C.; Smith, A.; Wheatley, A.; Forsythe, S.; J. Biotechnol. 2003, 101, 49.

3. Brown, M. A.; DeVito, S. C.; Crit. Rev. Environ. Sci. Technol. 1993, 23, 249.

4. Sriskandakumar, T.; Opembe, N.; Chen, C.-H.; Morey, A.; Kingondu, C.; Suib, S. L.; J. Phys. Chem. A 2009, 113, 1523.

5. Chang, M.-C.; Shu, H.-Y.; Yu, H.-H.; Sung, Y.-C.; J. Chem. Technol. Biotechnol. 2006, 81, 1259.

6. Hou, M.; Li, F.; Liu, X.; Wang, X.; Wan, H.; J. Hazard. Mater. 2007, 145, 305.

7. Shu, H.-Y.; Chang, M.-C.; Yu, H.-H.; Chen, W.-H.; J. Colloid Interface Sci. 2007, 314, 89.

8. Lin, Y.-T.; Weng, C.-H.; Chen, F.-Y.; Sep. Purif. Technol. 2008, 64,26

9. Chen, Z.; Jin, X.; Chen, Z.; Megharaj, M.; Naidu, R.; J. Colloid Interface Sci. 2011, 363, 601.

10. Saad, R.; Thiboutot, S.; Ampleman, G.; Dashan, W.; Hawari, J.; Chemosphere 2010, 81, 853.

11. Kharisov, B. I.; Dias, H. V. R.; Kharissova, O. V.; Jiménez-Pérez, V. M.; Pérez, B. O.; Flores, B. M.; RSC Adv. 2012, 2, 9325.

12. Mitchell, K. K. P.; Liberman, A.; Kummel, A. C.; Trogler, W. C.; J. Am. Chem. Soc. 2012, 134, 13997.

13. Lartigue, L.; Alloyeau, D.; Kolosnjaj-Tabi, J.; Javed, Y.; Guardia, P.; Riedinger, A.; Péchoux, C.; Pellegrino, T.; Wilhelm, C.; Gazeau, F.; ACS Nano 2013, 7, 3939.

14. Verma, S.; Verma, D.; Sinha, A. K.; Jain, S. L.; Appl. Catal., A 2015, 489, 17.

15. Baig, R. B. N.; Varma, R. S.; Green Chem. 2013, 15, 398.

16. Baig, R. B. N.; Varma, R. S.; Chem. Commun. (Cambridge, U. K.) 2013, 49, 752.

17. Verma, S.; Baig, R. B. N.; Han, C.; Nadagoudab, M. N.; Varma, R. S.; Chem. Commun. (Cambridge, U. K.) 2015, 51, 15554.

18. Verma, D.; Verma, S.; Sinha, A. K.; Jain, S. L.; ChemPlusChem 2013, 78, 860 .

19. Panda, N.; Sahoo, H.; Mohapatra, S.; J. Hazard. Mater. 2011, $185,359$.

20. Kharissova, O. V.; Dias, H. V. R.; Kharisov, B. I.; Pérez, B. O.; Pérez, V. M. J.; Trends Biotechnol. 2013, 31, 240.
21. Weng, X.; Huang, L.; Chen, Z.; Megharaj, M.; Naidu, R.; Ind. Crops Prod. 2013, 51, 342.

22. Hoag, G. E.; Collins, J. B.; Holcomb, J. L.; Hoag, J. R.; Nadagouda, M. N.; Varma, R. S.; J. Mater. Chem. 2009, 19, 8671.

23. Wang, Z.; Fang, C.; Megharaj, M.; ACS Sustainable Chem. Eng. 2014, 2, 1022.

24. Tandon, P. K.; Shukla, R. C.; Singh, S. B.; Ind. Eng. Chem. Res. 2013, 52, 10052.

25. Markova, Z.; Novak, P.; Kaslik, J.; Plachtova, P.; Brazdova, M.; Jancula, D.; Siskova, K. M.; Machala, L.; Marsalek, B.; Zboril, R.; Varma, R.; ACS Sustainable Chem. Eng. 2014, 2, 1674.

26. Shahwan, T.; Sirriah, S. A.; Nairat, M.; Boyacı, E.; Eroğlu, A. E.; Scott, T. B.; Hallam, K. R.; Chem. Eng. J. (Amsterdam, Neth.) 2011, 172, 258.

27. Dutra, F. L. G.; Hoffmann-Ribani, R.; Ribani, M.; Quim. Nova 2010, 33, 119.

28. Wang, Z.; ACS Sustainable Chem. Eng. 2013, 1, 1551.

29. Hartwig, V. G.; Brumovsky, L. A.; Fretes, M. R.; J. Food Res. 2012, 1, 58.

30. Taghvaei-Ganjali, S.; Zadmard, R.; Saber-Tehrani, M.; Appl. Surf. Sci. 2012, 258, 5925.

31. Kumar, K. M.; Mandal, B. K.; Kumar, K. S.; Reddy, P. S.; Sreedhar, B.; Spectrochim. Acta, Part A 2013, 102, 128.

32. Mahdavi, M.; Namvar, F.; Ahmad, M. B.; Mohamad, R.; Molecules 2013, 18, 5954.

33. Huang, L.; Weng, X.; Chen, Z.; Megharaj, M.; Naidu, R.; Spectrochim. Acta, Part A 2014, 117, 801.

34. Lin, J.; Weng, X.; Jin, X.; Megharaj, M.; Naidu, R.; Chen, Z.; RSC Adv. 2015, 5, 70874.

35. Satapanajaru, T.; Chompuchan, C.; Suntornchot, P.; Pengthamkeerati, P.; Desalination 2011, 266, 218.

36. Zhu, B.-W.; Lim, T.-T.; Feng, J.; Chemosphere 2006, 65, 1137.

37. Wang, T.; Jin, X.; Chen, Z.; Megharaj, M.; Naidu, R.; Sci. Total Environ. 2014, 466, 210.

38. Wang, S.; Dyes Pigm. 2008, 76, 714.

39. Fan, J.; Guo, Y.; Wang, J.; Fan, M.; J. Hazard. Mater. 2009, 166, 904.

40. Devi, L. G.; Kumar, S. G.; Reddy, K. M.; Munikrishnappa, C.; J. Hazard. Mater. 2009, 164, 459.

41. Kuang, Y.; Wang, Q.; Chen, Z.; Megharaj, M.; Naidu, R.; J. Colloid Interface Sci. 2013, 410, 67.

42. Hsueh, C. L.; Huang, Y. H.; Wang, C. C.; Chen, C. Y.; Chemosphere 2005, 58, 1409.

43. Labiadh, L.; Oturan, M. A.; Panizza, M.; Hamadia, N. B.; Ammar, S.; J. Hazard. Mater. 2015, 297, 34.

Submitted: November 22, 2015

Published online: April 4, 2016 